\title{
Anisotropic response of the Holzapfel's constitutive model for the lumbar spine considering degenerative conditions
}

\author{
Moustafa MOSBAH - Laboratory of numerical and experimental modeling of mechanical phenomena, \\ Department of Mechanical Engineering, University Abd El Hamid Ibn Badis of Mostaganem, Algeria \\ Монамmed BENDOUKHA - Laboratory of numerical and experimental modeling of mechanical \\ phenomena, Department of Mechanical Engineering, University Abd El Hamid Ibn Badis of Mostaganem, \\ Algeria" bendoukham@yahoo.fr \\ Érkezett: 2018. 02. 26. - Received: 26. 02. 2018. - https://doi.org/10.14382/epitoanyag-jsbcm.2018.20
}

\begin{abstract}
In order to study the risk of disc degeneration under load carriage, an osseo ligamentous FE model of the L4-L5 segment extracted from the validated lumbosacral model L1/S1 was used. Starting from CT images to simplified geometry, many programs and codes were used to simplify the geometry, assemble the mesh and formulate the bony structures of the segment. Abaqus 6.14 was used to pre and post analysis of the FE-model, which included a detailed calibrated model of intervertebral disc (IVD), The range of motion (ROM) curves, the intradiscal pressure, load-strain amount under pure physiological loads were considered for investigation. The model developed in this study considered the holzapfel anisotropy hyperelasticity of the annulus as well as a realistic description of the nucleus geometry, which allowed an improved representation of in vitro and in vivo experimental data during the validation process.

Keywords: intervertebral disc, L4-L5, range of motion finite element model, CT images, intradiscal pressure, Holzapfel anisotropy, hyperelasticity

Kulcsszavak: intervertebrális lemez, L4- L5, mozgásterjedelem végeselemes modellje, CT felvétel, intradiszkális nyomás, Holzapfel anizotrópia, hiperelaszticitás
\end{abstract}

\section{Introduction}

The disc degeneration is characterized by changes in the morphology and biochemistry of the IVD [16]. These biologic changes of disc degeneration are associated with back pain and other spinal disorders, such as disc herniation, spondylolisthesis, facet arthropathy, and stenosis. FE method is able to simulate a variety of clinical situations in a more way, and has been acting a fully matching partnership based on experimental approaches for spine biomechanics research [12]. The FE-models are widely used to provide an assessment of spine with spinal instrumentation and assist in the design, development and optimization of that spinal instrumentation. Advanced to other methods, these FE-models can predict the changes of stresses and strains in the IVD, vertebrae and ligaments and very comprehensive ROM data $[8,20]$. Our main objective is to review the most recent computational studies in the application of FE models that report the issue of research better understanding of low back pain and eventually treat the spinal disorders. Little experiments were performed on intact motion segments (Miller 1986, Lin 1978, Hirsch \& Nachemson 1954 ) and some on FSUs without posterior elements [2, 10, 13]. In the compression load case, the data from Brown 1957 is slightly lower than the generated values and the other experimental data. Some FE-models simulate the effects of degeneration [16], by simply removing some elements from the annulus fibrosus. Where others $[18,19,20]$ disclose the influence of geometrical, mechanical, or poromechanical parameters on IVD behavior without showing change in mechanical properties of degenerated IVD. More recently, recent poroelastic finite element model of the lumbar spine was developed to assess spinal response during physiological functions and behavior of degenerative disc $[15,16]$.

\section{Methods and materials}

A three-dimensional finite element (FE) model of the L4-5 FSU segment (Fig. 2) by modifying the mechanical properties of the intervertebral disc constituents [3]. All the bony structures including cortical and trabecular bone, whereas facet cartilage layers, annulus ground substance, nucleus pulposus and cartilage endplates were modeled by using solid hexahedral elements. The nucleus pulposus composed $43 \%$ of the whole volume of the disc. The symmetric FE-model of the human lumbar disc is developed to investigate the optimized properties required to mimic the intact by matching model predictions to experimental results. Facet joints simulated by a cartilaginous layer extruded in Abaqus along the vectors normal to the inferior face of the superior articular process to the central of thickness of $0.4 \mathrm{~mm}$ were modeled to be multi-linear elastic in compression [19] by surfaces-to surface contact with softened contact in the normal direction. [20] An initial typically gap of $0.2 \mathrm{~mm}$ was specified as reported [20]. The seven major ligaments were modeled as three dimensional, 4 noded Quad elements (T3D2) and allocated were as piecewise linear functions in stress-strain relationship $[7,8]$ as shown in Table. 1. This formulation allows simulation of changing ligament characteristics with different stress at a different level as a function of stress-strain. 


\begin{tabular}{|c|c|c|c|c|c|c|c|c|}
\hline Part & Structure & \multicolumn{3}{|c|}{ Young's modulus E (MPa) } & \multicolumn{2}{|c|}{ Poisson's ratio v } & Element type & Reference \\
\hline \multirow{6}{*}{ Vertebrae } & \multirow{2}{*}{$\begin{array}{l}\text { Trabecular bone } \\
\text { Cortical bone }\end{array}$} & \multicolumn{3}{|c|}{100} & \multicolumn{2}{|c|}{0.2} & & {$[8,14]$} \\
\hline & & \multicolumn{3}{|c|}{12,000} & \multicolumn{2}{|c|}{0.3} & & [8] \\
\hline & Posterior element & \multicolumn{3}{|c|}{3,500} & \multicolumn{2}{|c|}{0.25} & & {$[8,14]$} \\
\hline & Cartilaginous End plate & \multicolumn{3}{|c|}{23.8} & \multicolumn{2}{|c|}{0.4} & C3D8 & [20] \\
\hline & Facet cartilage & \multicolumn{3}{|c|}{11} & \multicolumn{2}{|c|}{0.4} & & {$[5,20]$} \\
\hline & Facet contact & \multicolumn{5}{|c|}{ Nonlinear soft contact } & Contact & {$[21,22]$} \\
\hline \multirow{3}{*}{ Annulus Fibrosus } & \multirow{2}{*}{ Healthy } & $\mathrm{C}_{10}$ & $\mathrm{C}_{20}$ & K1 & K2 & kappa & & \\
\hline & & 1.5715 & 9.2044 & 12.2 & 39.7 & 0.113 & C3D8 & [22] \\
\hline & Degenerated & 1 & 8.6 & 18.56 & 82.31 & 0.226 & & \\
\hline \multirow{2}{*}{ Nucleus Pulposus } & Healthy & \multirow{2}{*}{\multicolumn{5}{|c|}{ Incompressible fluid }} & \multirow{2}{*}{ F3D4 } & \multirow{2}{*}[6,19,21]{} \\
\hline & Degenerated & & & & & & & \\
\hline Ligaments & & \multicolumn{5}{|c|}{ Nonlinear stress-strain curve } & S4R & {$[7,8,21]$} \\
\hline
\end{tabular}

Table 1. Material properties used in FE Model

1. táblázat A végeselemes modellben használt anyagjellemzők

The entire model consists of approximately 424 S4R shell elements and 33360 hexahedral elements C3D8

\subsection{The intervertebral disc (IVD)}

The intervertebral disc was modeled using two separate structure (Figs. 2 and 5).

\subsection{The Nucleus Pulposus (NP)}

The Nucleus Pulposus (NP) exhibits a gelatinous core and, therein describes the mutually coupled behavior of both solid deformation and viscoelastic characteristics of fluid flow [7]. An initial hydrostatic pressure of $0.1 \mathrm{MPa}$ was prompted in the fluid filled cavity in the nucleus pulposus to simulate unloaded motion segments (Fig. 2) [17]. The healthy nucleus pulposus was modeled as incompressible fluid while the degenerated nucleus was defined as compressible fluid [10]

\subsection{The Annulus Fibrosus (AF)}

The Annulus Fibrosus (AF) was modeled as an anisotropic continuum structure, with deformation tensor [8], and the material coefficients $\mathrm{C}_{10}, \mathrm{C}_{20}, \mathrm{k}_{1}, \mathrm{k}_{2}$ and $\kappa$ were based on biaxial tension tests performed on healthy and degenerated annuli fibrosi [9]. The progression of degeneration was simulated using three model variants:

$$
\begin{aligned}
& W_{\text {matrix }}=C_{10}\left(I_{1}-3\right)+C_{20}\left(I_{1}-3\right)^{2} \\
& W_{\text {fibers }}=\frac{k_{1}}{2 k_{2}} \sum_{\alpha=4,6}\left(e^{k_{2}\left[(1-\kappa)\left(I_{1}-3\right)+k\left(I_{\alpha}-1\right)\right]^{2}}-1\right)
\end{aligned}
$$

The human healthy and degenerated intervertebral disc.were modeled using three structures:

(a) Healthy intervertebral disc (grade I) defined by healthy annulus and healthy nucleus;

(b) Moderate degeneration disc (grade III) defined by healthy annulus and degenerated nucleus;

(c) Severe degeneration disc (grade IV) defined by degenerated annulus and degenerated nucleus. The grading is based on the Thompson degeneration scale Fig. 1 .

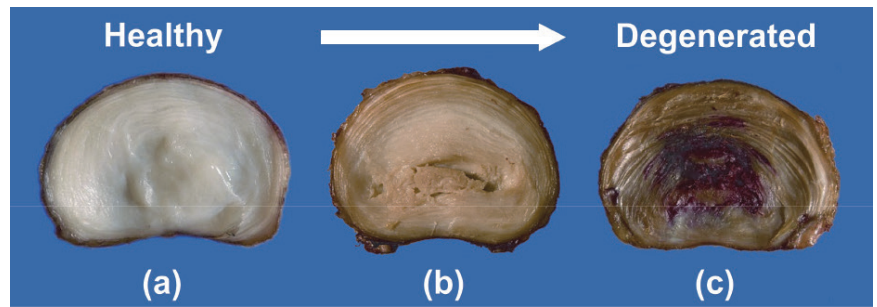

Fig. 1. (a) Healthy intervertebral discs; (b) moderate degeneration; (c) severe degeneration [23]

1. ábra (a) Egészséges intervertebrális lemez; (b) közepes mértékü károsodás; (c) súlyos károsodás [23]

\section{Model formulation}

The algorithms proposed in the present study is implemented into Abaqus as a User Material UMAT code embedded in an Python and Intel Fortran Compiler environment to simulate the biomechanical behavior of Annulus. This numerical approach consists on Holzapfel's hyperelastic constitutive models of the Annulus and a constitutive model of the seven major Ligaments, which were implemented in Abaqus via subroutines. The coefficients employed in all three conditions are listed in Table 1. While the material properties and in situ nuclear pressure were altered, osteophytes, local tears or similar macroscopic abnormalities were not modeled. Rather than attempting to simulate these defects of an independent individual and random nature, the focus was kept on the effects of measured changes in tissue behavior.

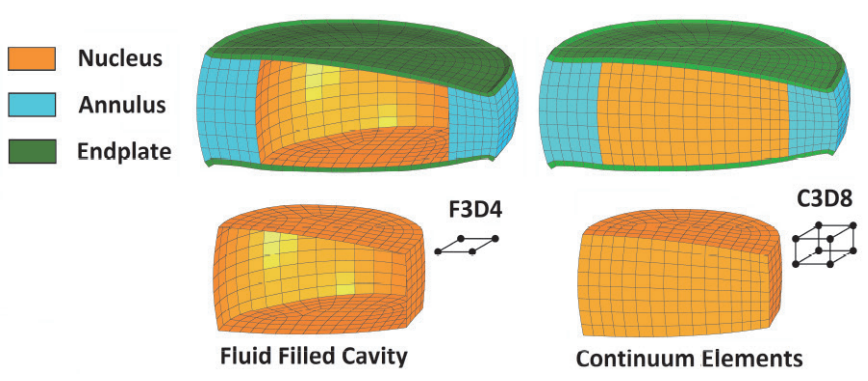

Fig. 2. Finite Element Model of the Intervertebral Disc IVD

2. ábra Intervertebrális lemez IVD végeselemes modellje 


\section{Loading and Boundary Conditions}

The IVD model comprises the intervertebral disc and the adjacent vertebral bodies. The lower vertebral body was rigidly fixed. Pure unconstrained axial compressive of $2000 \mathrm{~N}$ was applied to the upper vertebral body to the reference point which coupled all points on upper surface of the disc. The resulting stress-strain distribution at the center of the disc were estimate and the intradiscal Pressure IDP was predicted using the cavity point. Theoretically speaking, we used the concept of nucleus pulposus pressure measurement; by means of in vitro experiments on vertebra-disc-vertebra preparation whither, we found that the incompressible fluid pressure within the nucleus is directly related to the axial compression applied to the disc. The lower portion of the L5 vertebral body and its inferior facets were rigidly fixed. The load was applied through a reference node constrained to the upper surface of the L4 vertebrae using Abaqus Coupling Constraints elements (CCE). The L4/L5 Functional Spinal Unit (FSU) move in six different directions (six degrees of freedom (DOF)). A pure bending moment was incrementally increased $0,1,2.5,5,7.5,10 \mathrm{Nm}$ and applied to the model in all three planes of motion.

\section{Results}

\subsection{ROM results}

The finite element model predicted an increase in hydrostatic stress in the middle regions of the annulus by nearly seven fold. The intradiscal pressure IDP is considered to be very significant component to approximate internal stress behavior of the intervertebral disc. The in vitro measurements of the nucleus pressure in human intervertebral discs have shown proportion between IDP pressure and applied Load on the superior surface motion (ROM) in all loading directions except for lateral bending comparing to experimental.

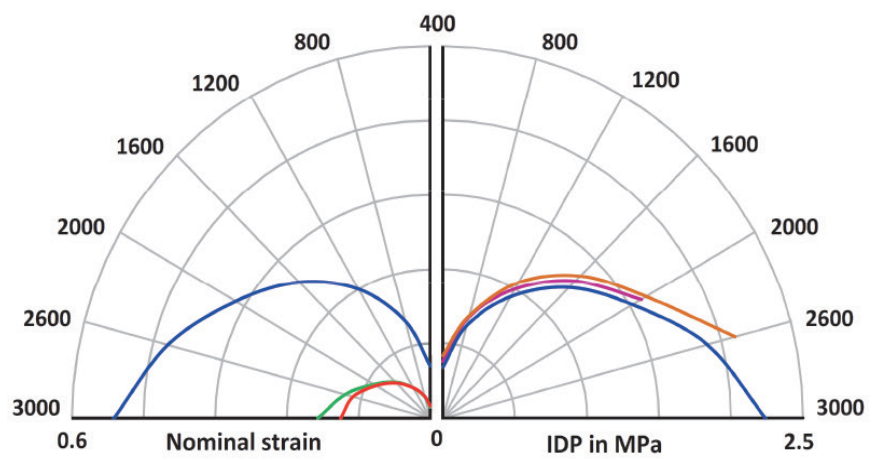

(a)

(b)

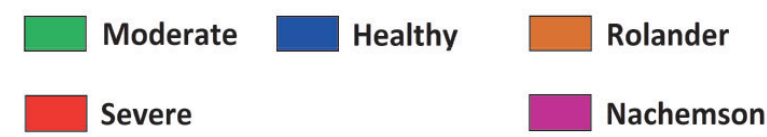

Fig. 3. (a) Comparison of intradiscal pressure (IDP) of the Healthy model with experimental results $(b)$ Comparison of nominal strain of fibers against the Load (N) of Healthy, Moderate and Severe models

3. ábra (a) Kísérleti intradiszkális nyomás (IDP) összehasonlítása az egészséges modell alapján számított értékkel; (b) Szálmegnyúlás és terhelőerö összehasonlitása egészséges, közepes és súlyos modellben
The greatest changes between Healthy and Moderate and Severe models were predicted in axial rotation by $30 \%$ and 36 $\%$. In lateral bending, a $27 \%$ increase in ROM was predicted in the Severe scenario (with respect to the Healthy condition), while the change in the Moderate scenario was approximately 32\% (Fig. 4).

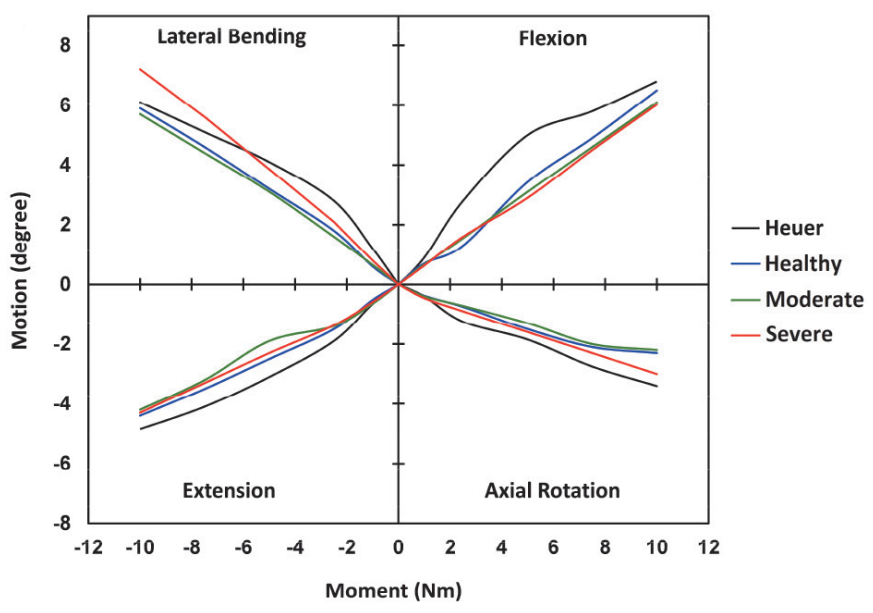

Fig. 4. ROM of L4-L5 FSU

4. ábra L4-L5 funkcionális szegmentális egység (FSU) mozgásterjedelme (ROM)

\subsection{Stress and strain results}

The analysis of the stress results allowed us to prove the most loaded region. As a most critical region for of spinal diseases, the presence of disc degeneration under physiological load steer to the alteration of the spine comportment and the pain function. The results for the body functions (Figs. 5-6) indicate that the superior values of the stresses were situated at posterior region which reaches stress of $2.9 \mathrm{MPa}$ for healthy disc and 2.4 MPa for the degenerated disc; as expected, the results highlight that the most risky load condition corresponds to posterior side. For the degenerated nucleus the results presented in Moderate degeneration a decreased stress according to strain decreasing comparing to Healthy IVD. Furthermore, the magnitude of stress predictions were reduced in the anterior region of the disc while they increased in the posterior region as the simulated degeneration progressed. In all cases, the highest stresses were concentrated in the posterior region of the disc in extension loading. The highest strain were concentrated in the posterolateral region of the disc in lateral bending loading as degeneration progressed (HealthyModerate-Severe). The compressive strain prediction in the annulus increased in anterior extremities in extension and in the posterior extremities in flexion Fig. 5.

\section{Discussion}

The aim of this work was to construct an accurate FEmodel to characterize the mechanical behavior of healthy and degenerated IVD. This model takes into account the IVD nature and also the clear preferential orientation of the collagen fibers in the annulus. The reduction in nonlinearity behavior with degeneration could suggest a diminished compaction effect of the degenerate tissues at large deformations which could be related to structural changes in annulus. The obtained 

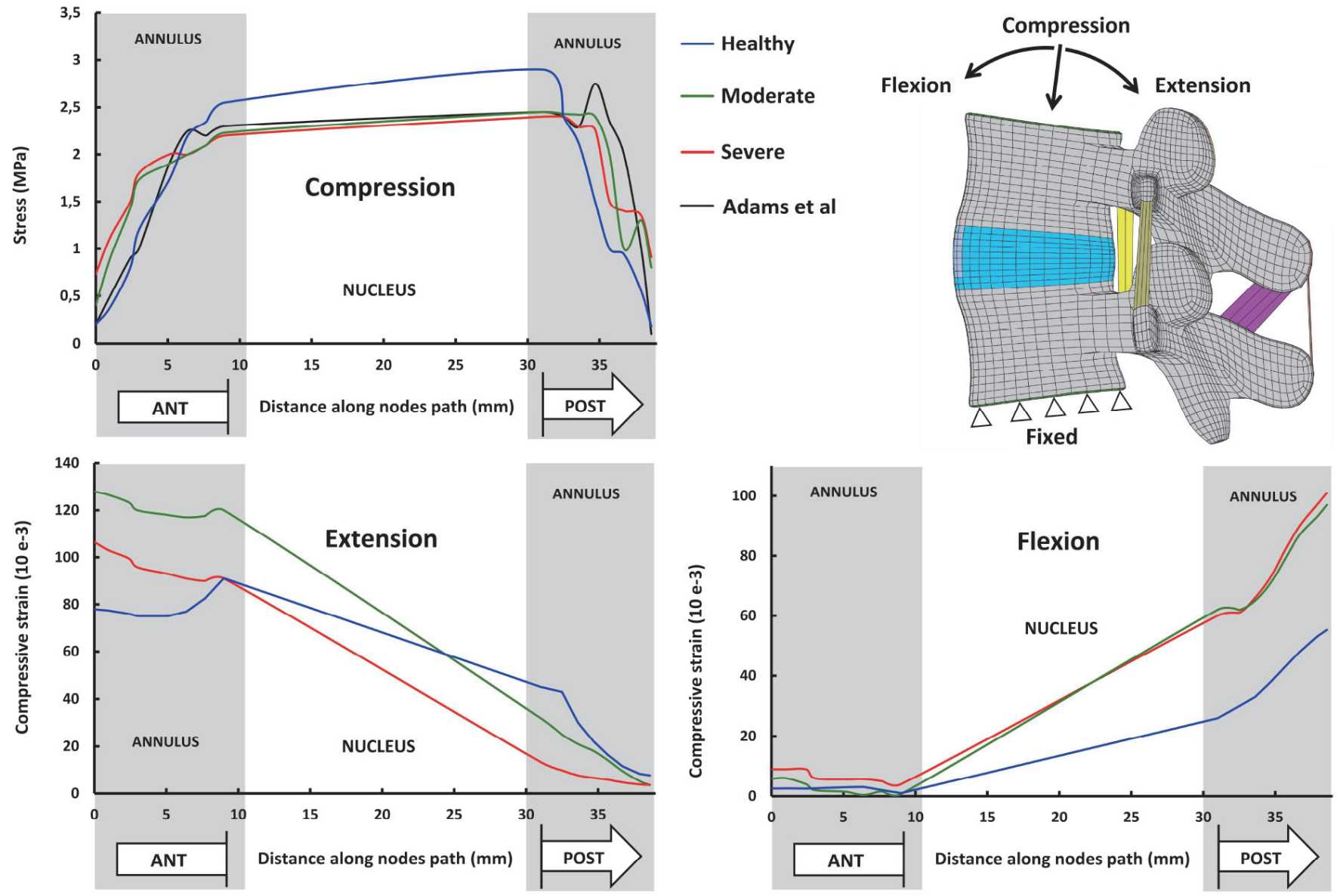

Fig. 5. Axial stress distribution and compressive strain predictions obtained from FE Models in the mid-height plane of the IVD from posterior to anterior midline under Compression (2000 N), Flexion and Extension (10 Nm).

5. ábra Tengelyirányú feszültségeloszlás és összenyomódás a végeselemes modell alapján az intervertebrális lemez középsíkjában, a posteriorból az anteriorba, nyomás (2000 N), hajlitás és megnyúlás (10 Nm) hatására

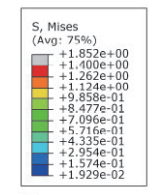

\section{Severe}
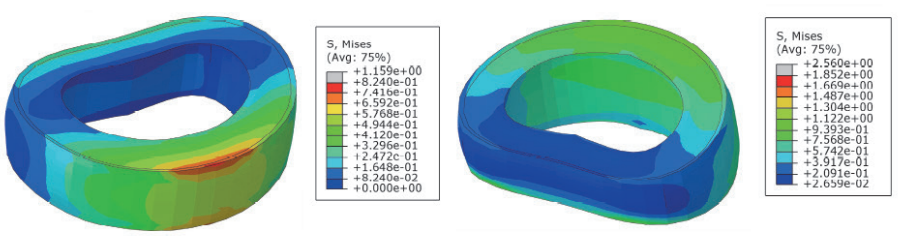

\section{Moderate}
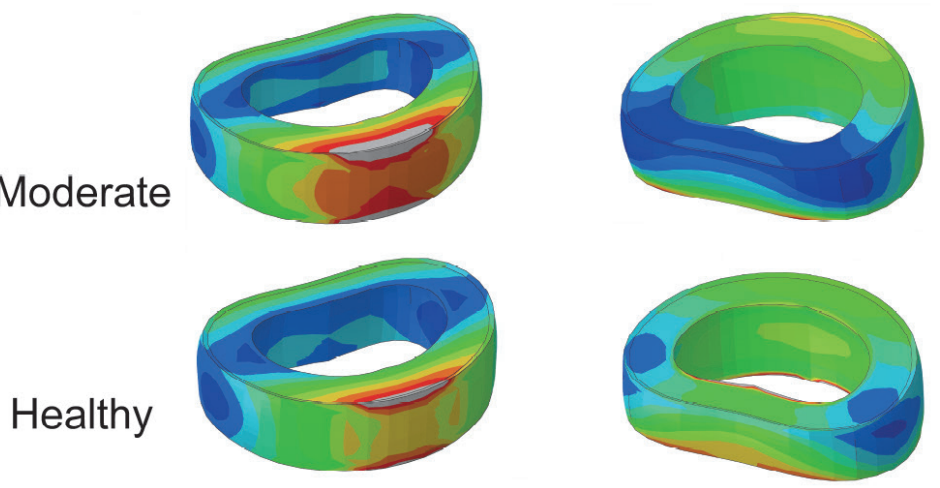

Flexion

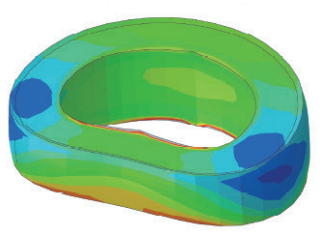

Extension
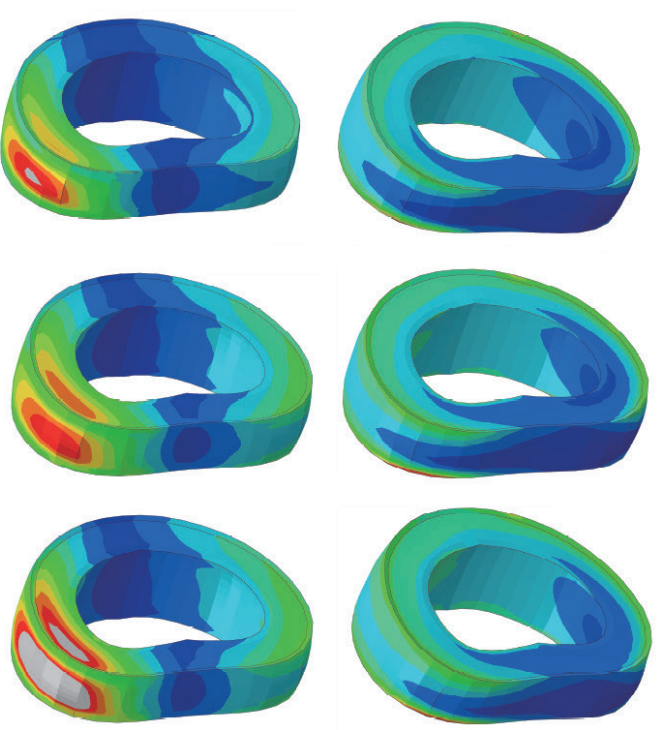

Lateral Bending

Axial Rotation

Fig. 6. Von-Mises Stress distribution obtained from FE Models: Healthy, Moderate, Severe

6. ábra Von-Mises feszültségeloszlás a végeselemes modell alapján egészséges, közepes és súlyos modellben 
results are also in agreement with the experimental behavior $[9,20]$. Experimental results, showed an increase of the elastic modulus in the toe part, thus there is a big role of fibers therefore when the fibers act there is no additional stiffening. In this analysis it has been obtained that the degeneration affects the biomechanics of this FSU; in particular an increase of the ROM in extension and partial decrease in flexion and lateral bending has been noticed.

\section{Conclusions}

In conclusion, the developed FE-model is capable of generating the mechanical behavior of normal and degenerated NP tissue with a favorable approximation. But on the degeneration of the other segments is a very complex procedure which should be identified in the degeneration of the AF tissue with accurate mechanical properties. Furthermore, the current work provides a qualitative analysis of the influence of single level disc degeneration on the mechanics of the segments under flexion/extension, lateral bending and axial rotation moments. It has been seen that degeneration modified the degree of motion and loading of the degenerated level. These changes could increase the risk of progression of degeneration to the nearest segments of the spine. The results obtained with the FE model seem to be in good agreement with invitro data as showed in Figs. 2 to 4 . Additionally, nonlinear analytical functions used in the IVD ligaments facet joint may be used as input data to perform more accurate computational simulations of the full lumbosacral spine.

\section{References}

[1] Berkeston, M - Schultz, A. B. (1979): Mechanical properties of human lumbar spine motion segments: II. Response in compression and shear; influence of gross morphology. Journal of Biomechanical Engineering 1979; 101:53-7. https://doi.org/10.1115/1.3426225

[2] Brown, T. - Hansen, R. J. - Yorra, A. J. (1957): Some mechanical tests on the lumbosacral spine with particular reference to intervertebral discs; a preliminary report. The Journal of Bone and Joint Surgery 1957, 39:11351164.

[3] Chazal, J. - Tanguy, A. - Bourges, M. - Gaurel, G. - Escande, G. - Guillot, M. (1985): Biomechanical properties of spinal ligaments and a histological study of the supraspinal ligament in traction, Journal of Biomechanics 18, 167-176, 1985. https://doi.org/10.1016/0021-9290(85)90202-7

[4] Chen, S. H. - Chiang, M. C. - Lin, J. F. - Lin, S. C. - Hung, C. H. (2013): Biomechanical comparison of three stand-alone lumbar cages-a three-dimensional finite element analysis. BMC Musculoskelet Disord. https://doi.org/10.1186/1471-2474-14-281

[5] Denoziere, G. - Ku, D. N. (2006): Biomechanical comparison between fusion of two vertebrae and implantation of an artificial intervertebral disc, Journal of Biomechanics, 39(4), 766-775. https://doi.org/10.1016/j.jbiomech.2004.07.039

[6] Dreischarf, M - Zander, T. - Shirazi-Adl, A. - Puttlitz, C. M. - Adam, C. J. - Chen, C. S. - Goel, V. K. - Kiapour, A. - Kim, Y. H. - Labus, K. M. - Little, J. P. - Park, W. M. - Wang, Y. H. - Wilke, H. J. - Rohlmann, A. Schmidt, H. (2014): Comparison of eight published static finite element models of the intact lumbar spine: Predictive power of models improves when combined together, Journal of biomechanics, Vol.47, No. 8, pp. 17571766, 2014. https://doi.org/10.1016/j.jbiomech.2014.04.002

[7] Eberlein, R. - Holzapfel, G. A. - Schulze-Bauer, C. A. J. (2001): An anisotropic model for annulus tissue and enhanced finite element analyses of intact lumbar disc bodies. Computer Methods in Biomechanics and Biomedical Engineering 2001;4(3):209-29

https://doi.org/10.1080/10255840108908005
[8] Goel, V. K. - Monroe, B. T. - Gilbertson, L. G. - Brinckmann, P. (1995): Interlaminar shear stresses and laminae separation in the disc. Finite element analysis of the L3-L4 motion segment subjected to axial compressive loads. Spine, 20(6), 689-698.

[9] Heuer, F. - Schmidt, H. - Klezl, Z. - Claes, L. - Wilke, H. J. (2007): Stepwise reduction of functional spinal structures increase range of motion and change lordosis angle, Journal of Biomechanics 40, 271- 280, 2007 https://doi.org/10.1016/j.jbiomech.2006.01.007

[10] Hirsch, C. - Nachemson, A. (1954): New Observations on the mechanical behavior of lumbar discs. Acta Orthopaedica Scandinavica 23 (4), 254283. https://doi.org/10.3109/17453675408991217

[11] Stokes, I. A. - Iatridis, J. C. (2004): Mechanical conditions that accelerate intervertebral disc degeneration: overload versus immobilization, Spine, Vol.29, No.23, pp.2724-2732, 2004.

[12] Urban, J. P. - Maroudas, A. - Bayliss, M. T. - Dillon, J. (1979): Swelling pressures of proteoglycans at the concentrations found in cartilaginous tissues, Biorheology, Vol.16, No.6, pp.447-464,1979. https://doi.org/10.3233/BIR-1979-16609

[13] Lin, H. S. - Liu, Y. K. - Adams, K. H. (1978): Mechanical response of the lumbar intervertebral joint 627 under physiological (complex) loading. The Journal of Bone and Joint Surgery 60A (1), 41-55.

[14] Lu, Y. M. - Hutton, W. C. - Gharpuray, V. M. (1996): Do bending, twisting, and diurnal fluid changes in the disc affect the propensity to prolapse? A viscoelastic finite element model. Spine Nov 1996, 21(22):2570-2579.

[15] Luoma, K. - Riihimaki, H. - Luukkonen, R. (2000): Low Back Pain in Relation to Lumbar Disc Degeneration. Spine, Vol. 25, No. 4, pp. 487-492

[16] Adams, M. A. - Roughley, P. J. (2006): What is intervertebral disc degeneration, and what causes it? Spine, Vol.31, no.18, pp. 2151-2161, 2006.

[17] Markolf, K. L. (1972): Deformation of the thoracolumbar intervertebral joints in response to external loads. The Journal of Bone and Joint Surgery 54-A:511-533, 1972

[18] Miller, J. A. A. - Schultz, A. B. - Warwick, D. N. - Spencer, D. L. (1986): Mechanical properties of lumbar spine motion segments under large loads. Journal of Biomechanics 19 (1), 79-84. https://doi.org/10.1016/0021-9290(86)90111-9

[20] Natarajan, R. N. - Andersson, G. B. (1999): The influence of lumbar disc height and cross-sectional area on the mechanical response of the disc to physiologic loading. Spine 1999; 24:1873-81.

[21] Rohlmann, A. - Zander, T. - Schmidt, H. - Wilke, H-J. - Bergmann, G. (2006): Analysis of the influence of disc degeneration on the mechanical behavior of a lumbar motion segment using the finite element method. Journal of Biomechanics 39:2484-2490.

https://doi.org/10.1016/j.jbiomech.2005.07.026

[22] Bendoukha, M. - Mosbah, M. (2017): Biomechanical Evaluation of Lumbosacral Segments Response under Physiological Functions: Finite Element Analysis. Épitöanyag - Journal of Silicate Based and Composite Materials, Vol. 69, No. 4 (2017), 122-126. p. https://doi.org/10.14382/epitoanyag-jsbcm.2017.21

[23] Illien-Jünger, S. - Walter, B. A. - Mayer, J. E. - Hecht, A. C. - Iatridis, J. C. (2014): Intervertebral Disc Culture Models and Their Applications to Study Pathogenesis and Repair. In: Shapiro I., Risbud M. (eds) The Intervertebral Disc. Springer, Vienna https://doi.org/10.1007/978-3-7091-1535-0_22

Ref.:

Mosbah, Moustafa - Bendoukha, Mohammed: Anisotropic response of the Holzapfel's constitutive model for the lumbar spine considering degenerative conditions Építőanyag - Journal of Silicate Based and Composite Materials, Vol. 70, No. 4 (2018), 110-114. p. https://doi.org/10.14382/epitoanyag-jsbcm.2018.20 